\title{
Use of LAMP Detection to Identify Potential Contamination Sources of Plant-Pathogenic Pythium Species in Hydroponic Culture Systems of Tomato and Eustoma
}

\author{
Wenzhuo Feng, ${ }^{\dagger}$ The United Graduate School of Agriculture Science, Gifu University, Gifu 501-1193, Japan; Akira Nukaya, Faculty \\ of Agriculture, Shizuoka University, Shizuoka 422-8529, Japan; Mamoru Satou and Naoko Fukuta, NARO Institute of Floricultural Sci- \\ ences, Fujimoto 2-1. Tsukuba, Ibaraki 305-8519, Japan; Yasushi Ishiguro, River Basin Research Center, Gifu University; Haruhisa Suga, \\ Life Science Research Center, Gifu University; and Koji Kageyama, River Basin Research Center, Gifu University
}

\begin{abstract}
Hydroponic culture systems are subject to high risks of diseases caused by zoosporic plant pathogens. Control is generally difficult because of the rapid spread of zoospores in the nutrient solutions. In Japan, tomato and eustoma, which are cultivated using the D-tray and nutrient film techniques, respectively, are susceptible to diseases caused by Pythium aphanidermatum and $P$. irregulare. We used loop-mediated isothermal amplification to identify potential contamination sources of these two pathogens by monitoring their presence in the water supply wells,

seedling terraces, nutrient solutions, diseased plants, and ground soils of a tomato greenhouse complex and a eustoma greenhouse complex. The results indicated that the pathogens may enter the culture systems from the soils around the greenhouses. Entry most likely occurs when seedlings are moved from the seedling terraces to the greenhouses, and sterilization of the hydroponic systems may not be sufficient. Therefore, monitoring pathogens in the culture systems and ground soils is very important for the management and prevention of these diseases.
\end{abstract}

Hydroponic culture systems are used in horticultural production because they provide the advantages of high yields and convenient management, and are independent of local soil conditions. However, these practices involve high risks of plant diseases caused by zoosporic plant pathogens. For example, the oomycetes Pythium aphanidermatum and Phytopythium helicoides, which cause root rot, can easily contaminate hydroponic culture systems and spread rapidly via the zoospores, resulting in serious crop losses (Li et al. 2014; Miyake et al. 2017; Stanghellini and Rasmussen 1994; Watanabe et al. 2008). Pythium spp. are destructive pathogens with an extensive host range throughout the world (Domsch et al. 1980; Van der Plaats-Niterink 1981). Once these pathogens are introduced into hydroponic culture systems, their control is generally difficult and commonly requires the shutdown and intensive disinfestation of the entire system. Furthermore, chemical control is difficult, because registered fungicides are restricted to prevent pollution of water resources.

Plant diseases often appear as nutrient deficiencies, resulting in visual symptoms such as chlorosis, interveinal chlorosis, stunting, and purpling (McCauley et al. 2009). There are many difficulties associated with interpreting visible symptoms. Disease symptoms can be caused by some abiotic stresses, including drought, salinity, heat, cold, chilling, freezing, nutrient, high light intensity, and ozone $\left(\mathrm{O}^{3}\right)$ stresses (Agarwal and Grover 2006; Baligar and Fageria 2015; Chaves and Oliveira, 2004; Lim et al. 2015; Mittler 2006; Wang et al. 2003). In addition to abiotic stresses, plants also must confront threats of infection by plant pathogens (including viruses, bacteria, fungi, and oomycetes) and attack by herbivore pests (Atkinson and Urwin 2012; Tauzin and Giardina 2014). Although a diagnosis scheme to differentiate between classes of abiotic and biotic stress

${ }^{\dagger}$ Corresponding author: W. Feng; E-mail: wenzhuofeng@126.com

Funding: This research was funded by "The development of diagnostic manual of high-temperature tolerant Pythium species in hydroponic culture system" project and "The scheme to revitalize agriculture and fisheries in disaster area through deploying highly advanced technology" project of the Japanese Ministry of Agriculture Forestry and Fisheries.

Accepted for publication 1 February 2018.

(c) 2018 The American Phytopathological Society factors using visible symptoms has been proposed (Vollenweider and Günthardt-Goerg 2005), it remains difficult to diagnose plant diseases caused by pathogens based on visual symptoms alone. For instance, zoospores can spread rapidly in the nutrient solutions of hydroponic culture systems; therefore, it is extremely important to develop rapid diagnostic methods to identify zoosporic plant pathogens due to their extremely rapid transmission. Appropriate and effective precautionary strategies can then be applied to hydroponic culture systems.

The traditional method for detecting and isolating Pythium spp. is based on the use of selective media containing antibacterial and antifungal agents, such as Pythium selective medium (Gamo et al. 2004). However, this approach cannot distinguish between pathogenic and nonpathogenic Pythium spp. that could be simultaneously present in hydroponic culture systems (Watanabe et al. 2008). Molecular detection techniques have been developed for fungi, viruses, and other microorganisms, including Pythium. Polymerase chain reaction (PCR)-based techniques, including conventional PCR (Kageyama et al. 1997), multiplex PCR (Asano et al. 2010; Ishiguro et al. 2013), and real-time PCR (Li et al. 2014; Schroeder et al. 2006), can be used to detect Pythium spp. However, PCR is time consuming, requires specialized skills and equipment, and most importantly, is difficult to use for on-site diagnosis in the field. To overcome the obstacles, recently, isothermal DNA amplification methods have been developed for replacing the tedious three-step thermal cycling PCR protocol, such as recombinase polymerase amplification (Miles et al. 2015), helicase-dependent amplification (Schwenkbier et al. 2015), and, especially, loop-mediated isothermal amplification (LAMP) (Feng et al. 2015).

The LAMP assay was developed by Notomi et al. (2000) and is an alternative nucleotide amplification method combining rapidity, simplicity, and high specificity. LAMP involves the use of Bst DNA polymerase, an enzyme that functions at a constant temperature and can, therefore, be completed without the use of a precision thermal cycler. The assay can be carried out in the field simply by using a water bath or heat block to incubate samples at a single temperature. Four different primers are used to amplify six independent DNA regions, allowing for high specificity. The reaction can be visually monitored due to the precipitation of magnesium pyrophosphate during amplification, resulting in white turbidity (Mori et al. 2001, 2004). Alternatively, color indicators such as SYBR Green I and hydroxynaphthol blue can be used to monitor the reaction (Goto et al. 2009; Iwamoto et al. 2003). 
The LAMP assay does not require purified DNA and can be used to detect Pythium spp. quickly and easily in plant roots, soils, and solutions (Feng et al. 2015; Kitamura et al. 2016; Miyake et al. 2017; Shen et al. 2017). Feng et al. (2015) developed the methods of plantor bait-LAMP and Plant or bait-culture LAMP to detect Pythium irregulare in plants and soils. For plant-LAMP, diseased root segments are simply mixed with distilled water and the supernatant liquid is used directly for amplification. For plant-culture LAMP, the diseased samples are placed in a culture medium and incubated for 1 day; then, the medium is mixed with water and used for amplification. The bait-LAMP technique is used to detected $P$. irregulare in soils. Autoclaved perilla seed (the bait) are placed in a water-soil suspension (the template DNA source) and incubated for 1 week. The seed are then removed and mixed with distilled water before amplification. In the bait-culture technique, the seed are incubated in a water-soil suspension as described above, then removed and placed in a culture medium for a day before amplification. Miyake et al. (2017) developed bait-LAMP and bait-culture LAMP methods to detect Phytopythium helicoides in hydroponic solutions. In both cases, the culture steps increased the sensitivity of the assays.

Recently, LAMP has been used for the simple detection of a wide range plant pathogens, including viruses, viroids, fungi, bacteria, and oomycetes (Boubourakas et al. 2009; Fukuta et al. 2012; Miyake et al. 2017; Rigano et al. 2010; Tomlinson et al. 2010). Due to the wide range of practicality and simplicity of the technique, it has become evident that LAMP would be an excellent method to monitor pathogens in hydroponic culture systems.

Since 2013, a wilting disease caused by Pythium aphanidermatum resulted in enormous losses in the yields of tomato cultivated in hydroponic systems in Shizuoka Prefecture (Li et al. 2014). These tomato plants are grown using the D-tray cultivation system that consists of a D-tray $(60 \mathrm{~cm}$ in length, $20 \mathrm{~cm}$ in width, and $10 \mathrm{~cm}$ in height) characterized by 10 connected $\mathrm{D}$-shaped pots $(250 \mathrm{ml} /$ pot $)$ regularly arranged in two rows. This cultivation system results in fruit with a high sugar content while requiring low-cost nutrients, substrate materials, and labor inputs (Tamai 2014; Zhang et al. 2015). In Fukushima Prefecture in 2011, the unprecedented accident at the nuclear power plant seriously contaminated the environment, including farmland. This event led to the introduction in 2014 of a hydroponic culture system named the nutrient film technique (NFT) to cultivate the cut flower eustoma. In this kind of culture system, no soil is used and the oxygen-rich nutrient solution is recycled, so that plants can be grown without the addition of contaminated soil or water from the environment. Unfortunately, root rot caused by $P$. irregulare has resulted in severe yield losses in the hydroponically grown eustoma in Fukushima Prefecture. In both the tomato and eustoma culture systems, heat sterilization is used after each cultivation period; however, this approach has not been adequate to eliminate the diseases.

The objectives of this study were to use the LAMP method to detect $P$. aphanidermatum in the tomato hydroponic culture system and $P$. irregulare in the eustoma culture system, and to identify potential contamination sources of these two pathogens. These studies will contribute to the development of more effective control strategies.

\section{Materials and Methods}

Greenhouses for tomato cultivation. Three greenhouses (A to C) were established in Shizuoka Prefecture to use the D-tray cultivation system. These greenhouses occupied an area of $4,000 \mathrm{~m}^{2}$, which also included a seedling terrace for the axenic cultivation of seedlings (Fig. 1A). The planting density was approximately 3.6 to 5.4 plants $/ \mathrm{m}^{2}$. During a 1-year period, three cultivation cycles were carried out, each involving the stages of transplanting, harvesting, cleaning, and heat sterilization treatment. The timing of these cycles varied between greenhouses, and greenhouse $\mathrm{C}$ was divided into separate east and west sections in which the timing differed. Seedlings were cultivated for 2 to 3 weeks on the seedling terrace in a potting mix based on pearlite and peat moss and irrigated with the nutrient solution, then transplanted into D-trays with a peat-moss-based potting mix. A small amount of nutrient solution (30 to $60 \mathrm{ml}$ ) was dripped into the Dtrays every day, and the discharged solution was collected and recirculated. The heat-treated nutrient solution and cultivation equipment were replaced before each new planting.

Greenhouses for eustoma cultivation. Three greenhouses ( 1 to 3) were set up for eustoma cultivation using the NFT in Fukushima Prefecture. Each greenhouse contained six cultivation blocks. The greenhouses occupied an area of $4,050 \mathrm{~m}^{2}$, which also included a seedling terrace (Fig. 1B). Using the NFT, 2.5 cropping cycles per year were achieved that included the processes of transplanting, harvesting, cleaning, and heat sterilization. In this production system, the nutrient solution was recirculated past the bare plant roots in a watertight gully. The nutrient solution and heat-treated cultivation equipment were replaced between cropping cycles. Seedlings were cultivated on the seedling terrace in a peat-moss-based potting mix irrigated with the nutrient solution.

Collection of nutrient solution, root, and soil samples. In the tomato greenhouses, nutrient solution samples were collected from the drainage recovery tanks before heat sterilization in the greenhouses and the seedling terrace every 2 weeks from March 2013 to March 2014. At the same time, we also collected water samples from the water supply well. In the eustoma greenhouses, the nutrient solution samples were collected from the drainage recovery tanks of each block and the seedling terrace before heat sterilization every month from March 2015 to February 2017. During the same monitoring periods in all greenhouses, diseased plants were identified by their symptoms of wilting and root discoloration. Root samples were collected from the diseased plants before the plants were discarded. In addition, from 19 December 2016, eustoma roots were collected together with nutrient solutions every month, even if no disease occurred. Soil samples ( $200 \mathrm{~g}$ ) were collected from various locations both inside and outside the greenhouses, including the seedling terraces; from the refuse discard areas; and from the waste water outlet areas of both greenhouse complexes (Fig. 1). The soil samples were collected once, in March 2013, at the tomato greenhouses and five times at the eustoma greenhouses, from March 2015 to February 2017.

Primer sets and LAMP reaction. We used specific LAMP primer sets that had been designed for $P$. aphanidermatum and $P$. irregulare by Fukuta et al. (2013) and Feng et al. (2015), respectively (Table 1 ). The LAMP reactions were carried out in total volumes of $15 \mu \mathrm{l}$ for detection of $P$. irregulare and $25 \mu \mathrm{l}$ for detection of $P$. aphanidermatum. Each contained $1.6 \mu \mathrm{M}$ each FIP and BIP primer, $0.2 \mu \mathrm{M}$ each F3 and B3 primer, $0.8 \mu \mathrm{M}$ each F-loop and B-loop primer (P. aphanidermatum only), $20 \mathrm{mM}$ Tris- $\mathrm{HCl}(\mathrm{pH} 8.8)$, $10 \mathrm{mM} \mathrm{KCl}, 0.1 \%$ (vol/vol) Tween $20,0.8 \mathrm{M}$ betaine (SigmaAldrich, St. Louis), $8 \mathrm{mM} \mathrm{MgSO}{ }_{4}, 10 \mathrm{mM}\left(\mathrm{NH}_{4}\right)_{2} \mathrm{SO} 4,1.4 \mathrm{mM}$ dNTPs (New England Biolabs Japan, Tokyo), 4.8 U (P. irregulare) or $8 \mathrm{U}$ ( $P$. aphanidermatum) of the Bst DNA polymerase large fragment (Nippon Gene Co. Ltd., Toyama, Japan) and template DNA (100 pg for the specificity test). The mixtures were incubated for $60 \mathrm{~min}$ at $67.5^{\circ} \mathrm{C}$ for $P$. irregulare and $68^{\circ} \mathrm{C}$ for P. aphanidermatum. Real-time changes in turbidity were recorded using a loopamp realtime turbidimeter (LA-200; Teramecs, Kyoto, Japan). The LAMP reactions were carried out in triplicate and controls contained positive DNA or distilled water in place of template DNA.

Detection of zoospores in nutrient solutions. We used a membrane filter technique named membrane-culture LAMP (MC-LAMP) to detect pathogens in the nutrient solutions. Each nutrient solution sample of 4 liters was filtered through a $5-\mu \mathrm{m}$-pore-size Durapore membrane (Millipore, Billerica, MA) to collect the pathogen spores (Hong et al. 2002). The membrane was then placed on a Pythium-selective medium containing nystatin, ampicillin, rifampicin, and miconazole (NARM) in a cornmeal agar medium (Morita and Tojo 2007) and cultured at $25^{\circ} \mathrm{C}$ for 1 day to encourage mycelial growth. About $0.1 \mathrm{~cm}^{3}$ of the medium containing mycelia was then excised and placed in a $1.5-\mathrm{ml}$ tube with $100 \mu \mathrm{l}$ of distilled water, and the tube was vortexed for $1 \mathrm{~min}$ using an MT-360 Multitube Fast Mixer (Tomy Seiko Co. Ltd., Kyoto, Japan). The supernatant liquid $(1 \mu \mathrm{l})$ was used directly as the template DNA in LAMP assays. 
Detection of pathogens in roots. The plant-culture LAMP method developed by Feng et al. (2015) was used to detect pathogens in plant tissues. Root samples from diseased tomato and eustoma plants were collected, and rotted or brown 1-cm segments (five per sample) were placed on NARM medium and incubated at $25^{\circ} \mathrm{C}$ for 1 day. The samples were then analyzed as described above for zoospores in the nutrient solutions.

Detection of pathogens in soil samples. The bait-culture LAMP method was used to detect pathogens in the soil samples (Feng et al. 2015). Each soil sample (200 g) was mixed thoroughly to generate a homogenous sample. Each homogenous soil sample (50 g) was mixed with $800 \mathrm{ml}$ of distilled water. A permeable envelope containing 50 autoclaved perilla seeds was added, and the mixture was incubated at $25^{\circ} \mathrm{C}$ for 1 week. The suspensions were shaken thoroughly every day. The seed were then removed, washed under tap water, placed on NARM medium, and incubated at $25^{\circ} \mathrm{C}$ for 1 day. These samples were then analyzed by LAMP, as described above.

\section{Results}

Detection of $\boldsymbol{P}$. aphanidermatum in tomato cultivation. In order to identify the potential contamination sources of $P$. aphanidermatum in tomato grown under the D-tray hydroponic culture system, we used the LAMP method to monitor the presence of $P$. aphanidermatum zoospores in the water supply well and the nutrient drainage

\section{A}

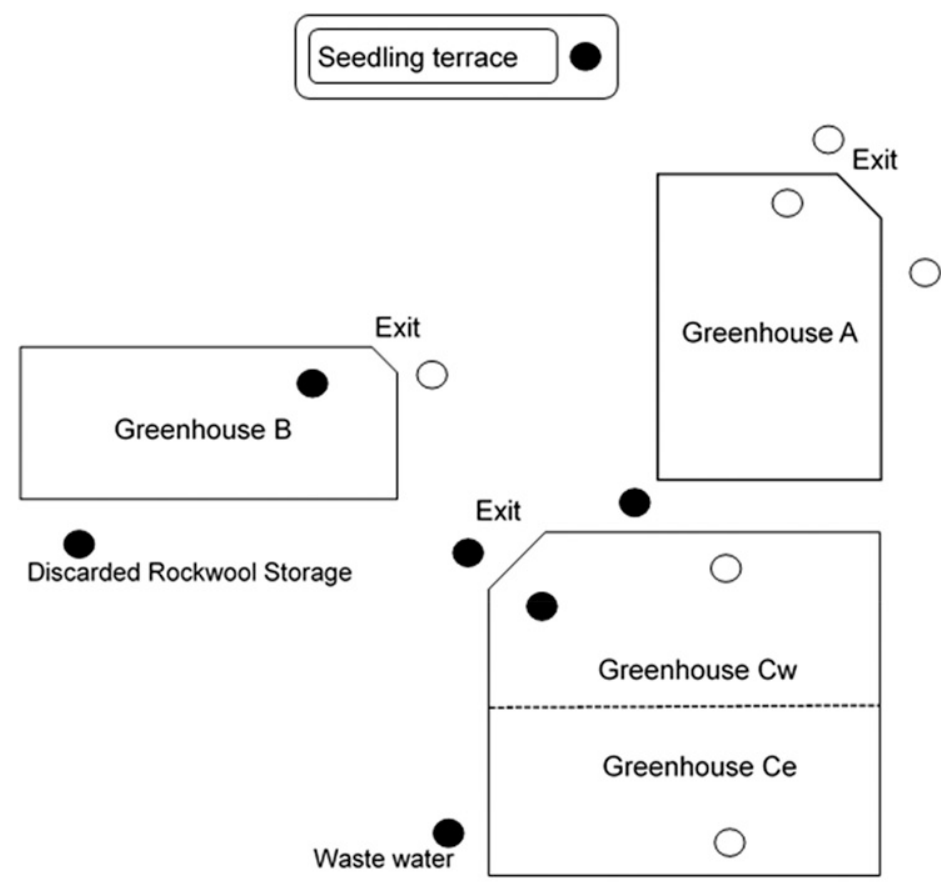

B

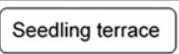

Greenhouse

Greenhouse
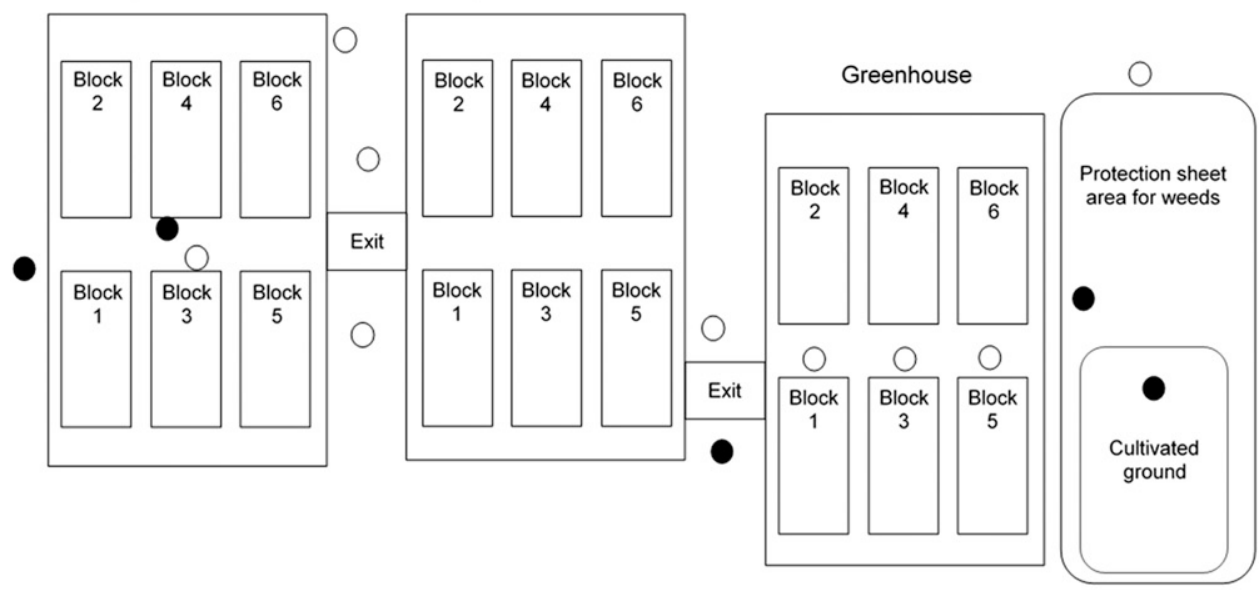

Waste wate

Discard area of plant

Fig. 1. Arrangement of greenhouses and seedling terraces in A, a tomato greenhouse complex and $\mathbf{B}$, a eustoma greenhouse complex. Soil samples were collected from sites indicated by circles. Sites where pathogens (Pythium aphanidermatum for tomato and $P$. irregulare for eustoma) were detected are indicated by filled circles ( $)$. The eustoma greenhouse complex included a grass field and vegetable cultivation ground, both of which had $P$. irregulare detected in March 2015 . To prevent the pathogen from invading the hydroponic system, a protective sheet was used to cover the area, including the cultivated ground. 
recovery tanks at the greenhouse complex in Shizuoka Prefecture, from March 2013 to March 2014. We also monitored the presence of the pathogen in diseased plants and in ground soils at various sites throughout the complex.

In all, 7 of 13 sites throughout the greenhouse complex where soil was sampled and tested by bait-culture LAMP in March 2013 were contaminated with the pathogen (Fig. 1A, filled circles). These seven sites included just inside the entrance of greenhouse $\mathrm{B}$, inside and outside the entrance of greenhouse C-west, the storage area for discarded rockwool, the waste water outlet area, and the front of the seedling terrace (Fig. 1A).

Twice per month, samples were taken from the water supply tank and the nutrient drainage recovery tanks in the greenhouses and the seedling terrace. Using the MC-LAMP technique, we detected $P$. aphanidermatum zoospores in the seedling terrace nutrient supply only once, on 19 July 2013, and no zoospores were detected in the supply water during the study period (data not shown). On the other hand, $P$. aphanidermatum zoospores were frequently detected in the drainage recovery tanks of all four greenhouse areas throughout the study period (Table 2).

During the same study period, disease symptoms were observed four times in greenhouse $\mathrm{A}$ and twice in greenhouse $\mathrm{C}$-east but did not occur in greenhouses B or C-west (Table 2). All of the diseased tomato roots gave positive results for $P$. aphanidermatum in the plant-culture LAMP assays.

Detection of $\boldsymbol{P}$. irregulare in eustoma cultivation. We conducted a similar experiment at a greenhouse complex in Fukushima Prefecture where eustoma is cultivated under the NFT culture system. The LAMP method was used to monitor $P$. irregulare in the water supply well, seedling terrace, and each greenhouse from March 2015 to February 2017. Diseased plants and ground soils were monitored during the same period.

The soil samples collected from a total of 9 of 18 sites gave positive results with the bait-culture LAMP method during the monitoring period (Fig. 1B). These nine sampling sites included surrounding farmlands, the discard area for plant residues, and the front of the seedling terrace.

Samples were collected once per month from the water supply well and the nutrient drainage recovery tanks of the seedling terrace and the 18 cultivation blocks ( 6 per greenhouse). During the 2-year monitoring period, $P$. irregulare was not detected by MC-LAMP in either the water supply well or the seedling terrace (data not shown). During the same period, the number of blocks where $P$. irregulare zoospores were detected in the drainage recovery tanks ranged from zero to four blocks (Fig. 2). The zoospores were detected 14 times during the first year (March 2015 to February 2016) and 32 times during the second year (Fig. 2). Data for all 14 blocks where $P$. irregulare zoospores were detected in the nutrient supply at least once during the monitoring period are shown in Tables 3 and 4 . Included in the table are the dates for the cropping cycles in each block, the dates when $P$. irregulare was detected in the nutrient supplies, the dates when disease was detected, and the growth stages of the diseased plants. In 5 of the 16 blocks, the pathogen was detected in two successive cropping cycles. In total, 22 transplantations were carried out during the 2-year study period (Fig. 3). P. irregulare was detected in at least one block on 13 of these transplantations. The pathogen was detected in multiple blocks on six of the transplantations (Fig. 3).

Disease occurred five times in greenhouse 1 and five times in greenhouse 3 during the study period. Of these 10 incidences, the disease occurred at the early growth stage of eustoma in 2 cases, the middle growth stage in 1 case, and the late growth stage in 7 cases (Table 3, Table 4). The diseased plant roots were collected, and $P$. irregulare was detected in all of the roots. The time between detection of zoospores in the nutrient solution and detection of disease was usually 1 or 2 months when the disease occurred at a middle or late growth stage (Table 3 ).

From mid-December 2016 until the end of the study period (February 2017), the eustoma plant roots were sampled every month at the same time as the nutrient solutions. $P$. irregulare was detected in plant roots in three blocks in December 2016, seven blocks in

Table 1. Loop-mediated isothermal amplification (LAMP) primer sets of Pythium aphanidermatum and P. irregulare used in this study ${ }^{\mathrm{a}}$

\begin{tabular}{lll}
\hline Target species, primers & \multicolumn{1}{c}{ Sequences $\left(\mathbf{5}^{\prime} \rightarrow \mathbf{3}^{\prime}\right)$} & Region amplified $^{\mathbf{b}}$ \\
\hline P. aphanidermatum & & \\
F3 & GCGACTTCGGTTAGGACATT & ITS \\
FIP & ACCACACTCTGTCAGCTGCAAC-GAAGCAACCTCTATTGGCGG & ITS \\
B3 & TGCCTCCTTTACCCTATCCG & ITS \\
BIP & TTGTGTGAGGCAATGGTCTGG-GTCCAAGAGCAGCAAAACC & ITS \\
F-Loop & CGGGCCGAAGCCTAACAT & ITS \\
B-Loop & GGTTGCTGTGTAGTAGGG & ITS \\
P. irregulare & & \\
F3 & CGTTTCTTCCTTCCGTGTAGT & ITS \\
FIP & GCAATCATTGCAAACAACTAACTCC-GGTGGAGGAGAGTTGCAGAT & ITS \\
B3 & ACCGCGAATCGAGGTCC & ITS \\
BIP & TCTTTTTTGTATGTGCGCGGTGC-TCACCGAAGTCGCCGAC & ITS \\
\hline
\end{tabular}

${ }^{a}$ LAMP primer set of $P$. aphanidermatum was designed by Fukuta et al. (2013) and of $P$. irregulare was designed by Feng et al. (2015).

${ }^{\mathrm{b}}$ ITS $=$ internal transcribed spacer.

Table 2. Monitoring of Pythium aphanidermatum and disease occurrence in tomato cultivation from March 2013 to March 2014

\begin{tabular}{|c|c|c|c|c|c|c|c|c|c|c|c|c|c|c|c|c|c|c|c|c|c|c|c|c|c|c|}
\hline \multirow[b]{2}{*}{ GH } & \multirow[b]{2}{*}{ Monitored } & \multicolumn{19}{|c|}{2013} & \multicolumn{6}{|c|}{2014} \\
\hline & & $3 / 6$ & $4 / 9$ & $4 / 23$ & $5 / 7$ & $5 / 21$ & $6 / 3$ & $6 / 18$ & $7 / 4$ & $7 / 19$ & $7 / 30$ & $8 / 13$ & $8 / 27$ & $9 / 10$ & $9 / 24$ & $10 / 8$ & $10 / 26$ & $11 / 9$ & $11 / 23$ & $12 / 12$ & $\overline{1 / 4}$ & $1 / 19$ & $2 / 1$ & $2 / 15$ & $3 / 1$ & $3 / 15$ \\
\hline \multirow[t]{2}{*}{ A } & Detection & + & NT & + & + & + & - & + & + & + & + & + & - & - & + & - & + & + & + & + & + & - & + & + & + & - \\
\hline & Diseas & - & NT & + & - & - & - & - & - & - & + & - & + & - & - & - & - & $T$ & - & - & - & - & - & - & - & - \\
\hline \multirow[t]{2}{*}{ B } & Detection & + & + & + & + & + & - & - & + & + & + & + & + & - & + & - & + & + & + & + & + & + & + & - & + & + \\
\hline & Disease & - & - & - & - & - & - & - & - & - & - & - & - & - & - & - & - & - & - & - & - & - & - & - & - & - \\
\hline \multirow[t]{2}{*}{$\mathrm{Ce}$} & Detection & + & - & + & - & + & + & + & + & + & + & + & - & - & + & + & + & + & + & + & + & + & + & - & - & - \\
\hline & Disease & - & - & - & - & - & + & + & - & - & - & - & - & - & - & - & - & - & - & - & - & - & - & - & - & - \\
\hline \multirow[t]{2}{*}{$\mathrm{Cw}$} & Detection & + & - & + & + & + & + & + & + & + & + & + & + & - & + & - & + & + & + & + & + & - & + & - & - & + \\
\hline & Disease & - & - & - & - & - & - & - & - & - & - & - & - & - & - & - & - & - & - & - & - & - & - & - & - & - \\
\hline
\end{tabular}

a Symbols: $+=P$. aphanidermatum was detected or disease occurred, $-=P$. aphanidermatum was not detected or no disease occurred, NT $=$ no test, GH $=$ greenhouse, $\mathrm{Ce}=$ greenhouse $\mathrm{C}$ east, $\mathrm{Cw}=$ greenhouse $\mathrm{C}$ west. Cropping cycles in each block are distinguished by alternating gray and white backgrounds. 


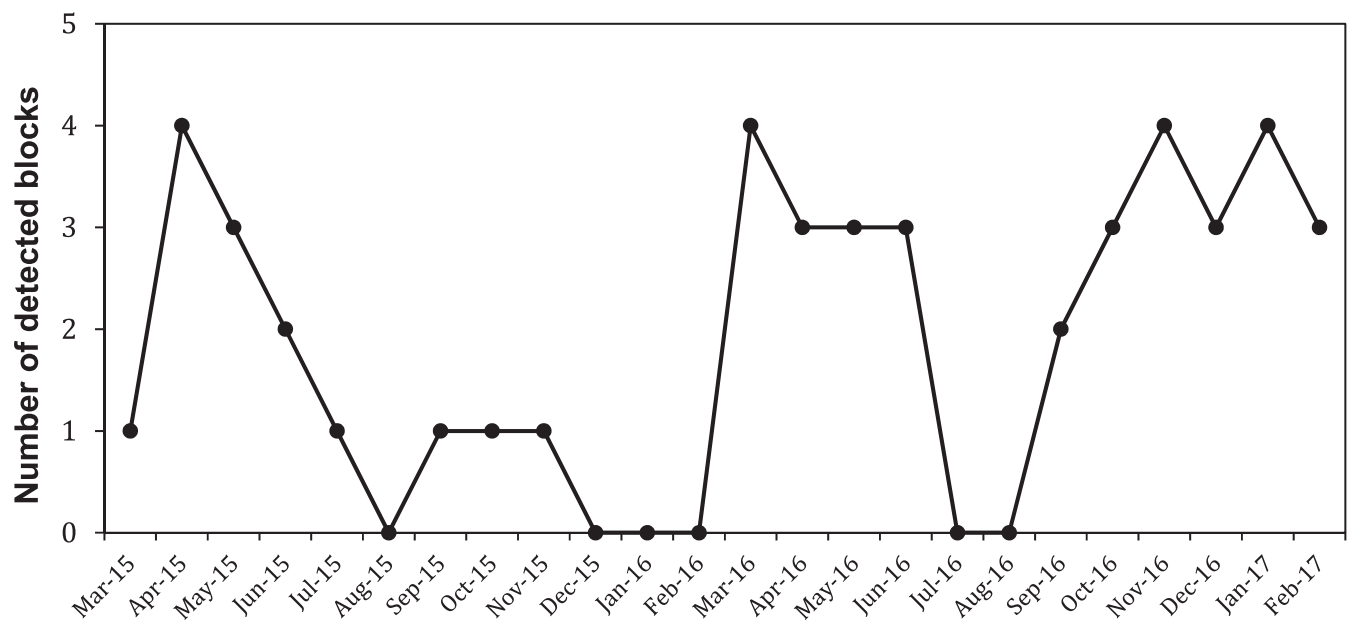

Nutrient solution sampling date

Fig. 2. Numbers of blocks in the eustoma greenhouses where Pythium irregulare was detected in the nutrient solution each month of the study period.

Table 3. Monitoring of Pythium irregulare and disease occurrence in eustoma cultivation from March 2015 to November 2016

\begin{tabular}{|c|c|c|c|c|c|c|c|c|c|c|c|c|c|c|c|c|c|c|c|c|c|c|}
\hline \multirow[b]{2}{*}{ GH, bl } & \multirow[b]{2}{*}{ Monitored } & \multicolumn{10}{|c|}{2015} & \multicolumn{11}{|c|}{2016} \\
\hline & & $\overline{\text { Mar }}$ & Apr & May & Jun & Jul & Aug & Sep & Oct & Nov & Dec & Jan & Feb & Mar & Apr & May & Jun & Jul & Aug & Sep & Oct & Nov \\
\hline \multicolumn{23}{|l|}{1} \\
\hline \multirow[t]{2}{*}{$1-1$} & Detection & - & NT & - & - & - & - & - & - & - & - & - & - & - & - & - & NT & - & NT & - & - & - \\
\hline & Disease & - & NT & - & - & - & - & - & - & - & - & - & - & - & - & - & NT & - & NT & - & - & - \\
\hline \multirow[t]{2}{*}{$1-2$} & Detection & NT & - & - & - & - & - & - & - & - & - & - & - & - & - & - & + & NT & - & - & - & + \\
\hline & Disease & NT & - & - & - & - & - & - & - & - & - & - & - & - & - & _- & - & NT & - & - & - & - \\
\hline \multirow[t]{2}{*}{$1-3$} & Detection & NT & + & - & - & - & - & - & - & - & - & - & - & + & + & + & NT & NT & NT & - & + & + \\
\hline & Disease & NT & $+(\mathrm{L})$ & - & - & - & - & - & - & - & - & - & - & - & - & $+(\mathrm{L})$ & NT & NT & NT & - & - & $+(\mathrm{L})$ \\
\hline \multirow[t]{2}{*}{$1-4$} & Detection & NT & - & - & - & - & - & - & - & - & NT & - & - & - & - & NT & - & NT & - & + & + & + \\
\hline & Disease & NT & - & - & - & - & - & - & - & - & NT & - & - & - & - & NT & - & NT & - & - & - & - \\
\hline \multirow[t]{2}{*}{$1-5$} & Detection & NT & NT & - & - & - & - & - & - & - & - & - & - & - & - & - & - & - & NT & - & - & - \\
\hline & Disease & NT & NT & - & - & - & - & - & - & - & - & - & - & - & - & - & - & - & NT & - & - & - \\
\hline \multirow[t]{2}{*}{$1-6$} & Detection & - & - & - & _- & - & - & _- & - & - & - & - & - & - & - & - & - & - & - & - & - & - \\
\hline & Disease & - & - & - & - & - & - & - & - & - & - & - & - & - & - & - & - & - & - & - & - & - \\
\hline \multicolumn{23}{|l|}{2} \\
\hline \multirow[t]{2}{*}{$2-1$} & Detection & NT & - & - & - & - & - & - & - & - & - & - & - & - & - & - & NT & - & - & - & - & - \\
\hline & Disease & NT & - & - & - & - & - & - & - & - & - & - & - & - & - & - & NT & - & - & - & - & - \\
\hline \multirow[t]{2}{*}{$2-2$} & Detection & NT & NT & - & - & - & - & - & - & - & - & - & - & - & - & - & - & - & - & + & NT & - \\
\hline & Disease & NT & NT & - & - & - & - & - & - & - & - & - & - & - & - & - & - & - & - & - & NT & - \\
\hline \multirow[t]{2}{*}{$2-3$} & Detection & NT & NT & - & - & - & - & - & - & - & - & - & - & - & - & + & + & - & - & - & + & - \\
\hline & Disease & NT & NT & - & - & - & - & - & - & - & - & - & - & - & - & - & - & - & - & - & - & - \\
\hline \multirow[t]{2}{*}{$2-4$} & Detection & NT & - & + & - & - & - & - & - & - & - & - & - & - & - & - & - & - & - & - & - & - \\
\hline & Disease & NT & - & - & - & - & - & - & - & - & - & - & - & - & - & - & - & - & - & - & - & - \\
\hline \multirow[t]{2}{*}{$2-5$} & Detection & NT & + & + & + & - & - & - & - & - & - & - & - & - & - & - & - & - & - & - & - & - \\
\hline & Disease & NT & - & - & - & - & - & - & - & - & - & - & - & - & - & - & - & - & - & - & - & - \\
\hline $2-6$ & Detection & - & - & - & - & + & - & - & - & - & NT & - & - & - & - & - & - & - & - & - & - & - \\
\hline & Disease & - & - & - & - & - & - & - & - & - & NT & - & - & - & - & - & - & - & - & - & - & - \\
\hline 3 & & & & & & & & & & & & & & & & & & & & & & \\
\hline $3-1$ & Detection & NT & NT & - & - & - & - & - & - & - & - & - & - & - & - & NT & - & - & - & NT & - & - \\
\hline & Disease & NT & NT & - & - & - & - & - & - & - & - & - & - & - & - & NT & - & - & - & NT & - & - \\
\hline $3-2$ & Detection & NT & - & - & - & - & - & - & - & - & - & - & - & + & + & + & - & - & - & NT & - & - \\
\hline & Disease & NT & - & - & - & - & - & - & - & - & - & - & - & - & $+(\mathrm{M})$ & - & - & - & - & NT & - & - \\
\hline $3-3$ & Detection & - & - & - & - & - & - & - & - & - & - & - & - & + & - & - & + & - & - & NT & - & - \\
\hline & Disease & - & - & - & - & - & - & - & - & - & - & - & - & - & - & - & - & - & - & NT & - & - \\
\hline $3-4$ & Detection & NT & + & - & - & - & - & - & - & - & - & - & - & - & - & - & - & - & - & NT & - & - \\
\hline & Disease & NT & - & - & - & - & - & - & - & - & - & - & - & - & - & - & - & - & - & NT & - & - \\
\hline $3-5$ & Detection & NT & - & - & - & - & - & - & - & - & - & - & - & - & - & NT & - & - & - & NT & - & - \\
\hline & Disease & NT & - & - & - & - & - & - & - & - & - & - & - & - & - & NT & - & - & - & NT & - & - \\
\hline $3-6$ & Detection & + & + & + & + & - & - & + & + & + & - & - & - & + & + & - & - & - & - & - & - & - \\
\hline & Disease & - & - & $+(\mathrm{L})$ & - & - & - & - & $+(\mathrm{L})$ & - & - & - & - & - & - & - & - & - & - & - & - & - \\
\hline
\end{tabular}

${ }^{\text {a }}$ Symbols: $\mathrm{GH}=$ greenhouse, $\mathrm{bl}=$ block,$+=P$. irregulare was detected or disease occurred, $-=P$. irregulare was not detected or no disease occurred, $\mathrm{NT}=$ no test, $(\mathrm{M})=$ disease occurred at the middle growth stage, and $(\mathrm{L})=$ disease occurred at the late growth stage. Cropping cycles in each block are distinguished by alternating gray and white backgrounds. 
January 2017, and three blocks in February 2017. The zoospores were detected in the nutrient solutions in three blocks in December 2016, four blocks in January 2017, and three blocks in February 2017. The pathogen was detected in healthy roots in five blocks but, in two of those blocks, the wilting disease occurred later (Table 4).

Table 4. Comparison of detection of Pythium irregulare between nutrient solutions (NS) and roots from December 2016 to February 2017

\begin{tabular}{|c|c|c|c|c|c|c|c|}
\hline \multirow[b]{2}{*}{ GH, block } & \multirow[b]{2}{*}{ Transplanting date } & \multicolumn{2}{|c|}{$\begin{array}{c}19 \\
\text { December } \\
2016\end{array}$} & \multicolumn{2}{|c|}{$\begin{array}{c}16 \\
\text { January } \\
2017\end{array}$} & \multicolumn{2}{|c|}{$\begin{array}{c}13 \\
\text { February } \\
2017\end{array}$} \\
\hline & & NS & Roots & NS & Roots & NS & Root: \\
\hline \multicolumn{8}{|l|}{1} \\
\hline $1-1$ & 19 December 2016 & - & NT & - & $+(\mathrm{E})$ & - & - \\
\hline $1-2$ & 15 December 2016 & - & NT & - & - & - & - \\
\hline $1-3$ & 19 December 2016 & + & NT & - & - & - & - \\
\hline $1-4$ & 15 December 2016 & - & NT & - & - & - & - \\
\hline $1-5$ & 19 December 2016 & - & NT & - & - & - & - \\
\hline $1-6$ & 15 December 2016 & - & NT & - & $+(\mathrm{E})$ & - & - \\
\hline \multicolumn{8}{|l|}{2} \\
\hline $2-1$ & 7 November 2016 & - & - & + & + & + & + \\
\hline $2-2$ & 7 November 2016 & - & - & + & + & + & + \\
\hline $2-3$ & 7 November 2016 & + & + & + & + & + & + \\
\hline $2-4$ & 7 November 2016 & - & - & - & - & - & - \\
\hline $2-5$ & 7 November 2016 & - & - & - & - & - & - \\
\hline $2-6$ & 7 November 2016 & - & - & - & - & - & - \\
\hline \multicolumn{8}{|l|}{3} \\
\hline \multirow[t]{2}{*}{$3-1$} & 30 September 2016 & - & - & - & - & $\ldots$ & $\ldots$ \\
\hline & 2 February 2017 & $\ldots$ & $\ldots$ & $\ldots$ & $\ldots$ & - & - \\
\hline \multirow[t]{2}{*}{$3-2$} & 30 September 2016 & - & + & - & $+(\mathrm{L})$ & $\ldots$ & $\ldots$ \\
\hline & 2 February 2017 & $\ldots$ & $\ldots$ & $\ldots$ & $\ldots$ & - & - \\
\hline \multirow[t]{2}{*}{$3-3$} & 30 September 2016 & - & - & - & - & $\ldots$ & $\ldots$ \\
\hline & 7 February 2017 & $\ldots$ & $\ldots$ & $\ldots$ & $\ldots$ & - & - \\
\hline \multirow[t]{2}{*}{$3-4$} & 30 September 2016 & + & + & - & $+(\mathrm{L})$ & $\ldots$ & $\ldots$ \\
\hline & 13 February 2017 & $\ldots$ & $\ldots$ & $\ldots$ & $\ldots$ & - & - \\
\hline \multirow[t]{2}{*}{$3-5$} & 30 September 2016 & - & - & + & - & $\ldots$ & $\ldots$ \\
\hline & 1 February 2017 & $\ldots$ & $\ldots$ & $\ldots$ & $\ldots$ & - & - \\
\hline \multirow[t]{2}{*}{$3-6$} & 30 September 2016 & - & - & - & - & $\ldots$ & $\ldots$ \\
\hline & 1 February 2017 & $\ldots$ & $\ldots$ & $\ldots$ & $\ldots$ & - & - \\
\hline
\end{tabular}

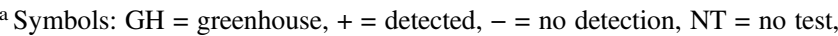
$(E)=$ disease occurred at the early growth stage, and $(\mathrm{L})=$ disease occurred at the late growth stage.

\section{Discussion}

In this study, the LAMP method was used to monitor zoosporic Pythium plant pathogens in greenhouses where tomato and eustoma plants were grown in hydroponic cultures. $P$. aphanidermatum was monitored in a greenhouse complex in Shizuoka Prefecture, where tomato plants were grown under the D-tray cultivation system, and $P$. irregulare was monitored in greenhouses in Fukushima Prefecture, where eustoma was grown under the NFT culture system. We used specific and sensitive LAMP primer sets designed by Fukuta et al. (2013) for $P$. aphanidermatum and Feng et al. (2015) for $P$. irregulare. The NARM selective medium was used to culture the pathogens from nutrient solution filtrates, diseased plant roots, and perilla seed that had been mixed with soil suspensions and incubated for 1 week. The mycelial outgrowth from the NARM medium was mixed with distilled water and used directly for LAMP detection. This simple detection process did not require the extraction and purification of DNA. Our results indicate that the LAMP method is effective for detecting $P$. aphanidermatum and $P$. irregulare in greenhouses where plants are grown under hydroponic conditions.

Some researchers reported that water temperature, zoospore concentration, application pressure, and so on have effects on the occurrence of disease caused by zoosporic plant pathogens (Banko et al. 2006; Granke and Hausbeck 2010). In terms of complex environmental factors in a hydroponic culture system, it is difficult to describe a quantitative threshold of disease based on the number of the pathogenic zoospores. Li et al. (2014) used real-time PCR to monitor and quantify three Pythium spp. under hydroponic culture systems. They found no obvious correlations between disease occurrence and the concentrations of the pathogenic zoospores evaluated by real-time PCR. This suggests that the simple and qualitative LAMP method is sufficient and reliable for monitoring and identifying the potential contamination sources of pathogens in hydroponic culture systems.

We monitored $P$. aphanidermatum in the water supply well and the seedling terrace at the tomato greenhouse complex and detected $P$. aphanidermatum once during the sampling period in the seedling terrace. This result indicated that there is a risk of introducing the pathogen to seedlings before transplanting. We frequently detected $P$. aphanidermatum zoospores in the nutrient solutions in the drainage recovery tanks in the greenhouses. However, the wilting disease of tomato occurred rarely over the monitoring period; it usually occurred during the early growth stage. The pathogen was detected in 8 of 13 soil samples collected inside and outside the greenhouses

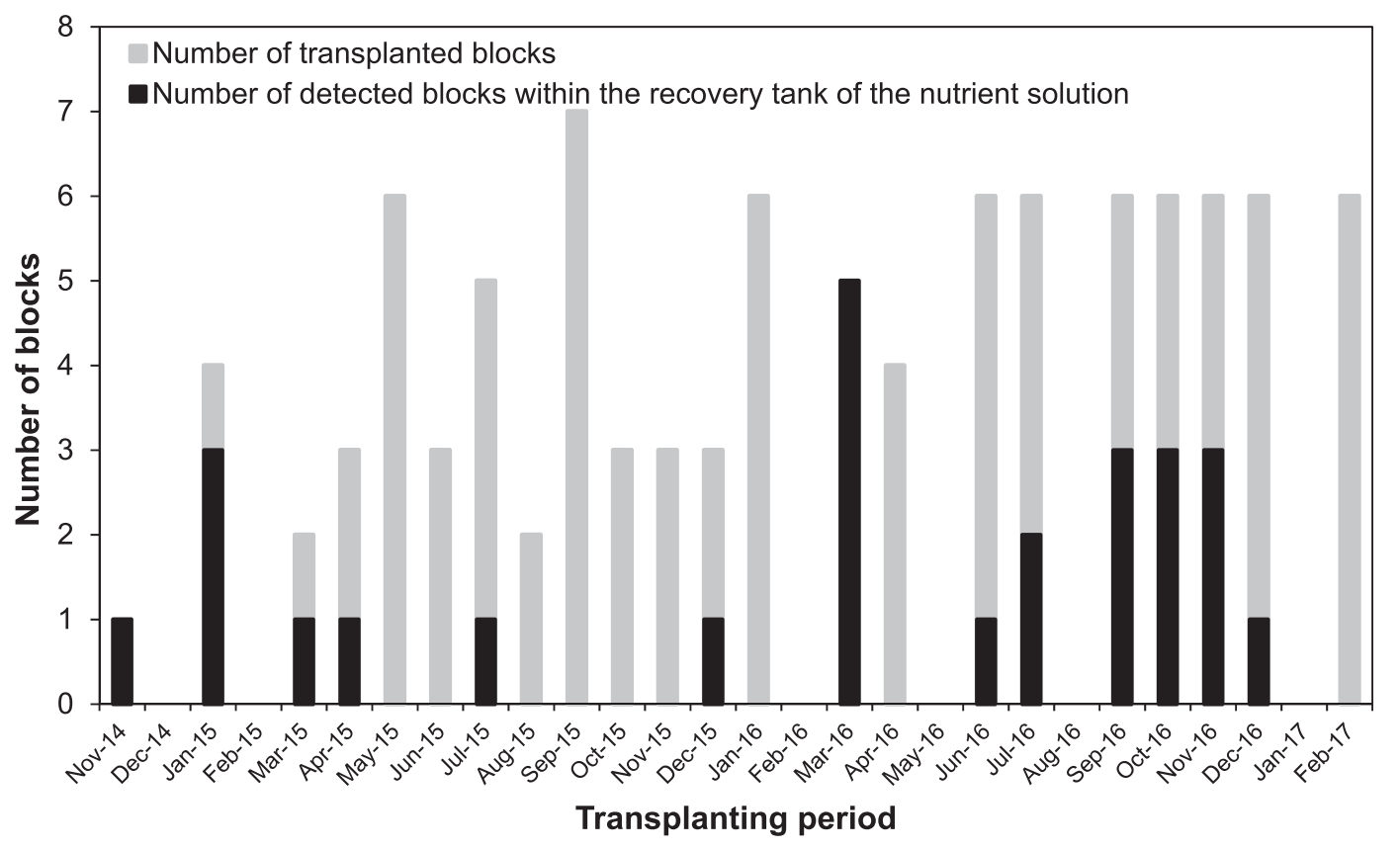

Fig. 3. Numbers of blocks that were transplanted each month in the eustoma greenhouses and the numbers of blocks that became infested with Pythium irregulare. 
and in front of the seedling terrace. These results indicated that (i) there was no obvious correlation between the detection of P. aphanidermatum and the occurrence of the disease, (ii) the heat sterilization of cultivation equipment and the replacement of heat-treated nutrient solutions between growth cycles may not be effective in completely removing the pathogens, and (iii) the possibility of introducing $P$. aphanidermatum from the surrounding soil into the greenhouses is very high, especially during the transplanting period.

Based on our brief identification of the potential contamination sources of $P$. aphanidermatum in tomato greenhouses, we implemented a 2-year study in a eustoma greenhouse complex infested with $P$. irregulare. $P$. irregulare was detected in the nutrient solutions in several blocks during most months of the study period. The $P$. irregulare infestations were not restricted to specific blocks; almost all of the blocks were infested at least once during the 2-year period. Also, wilting disease occurred multiple times in two of the greenhouses, and the pathogen was detected in all diseased plants. Our results indicated that the infestation of $P$. irregulare had become established and became more serious in the second year of the study period. Therefore, heat sterilization of the equipment between growth cycles was not effective in eliminating the pathogen.

$P$. irregulare was detected in soil samples collected both inside and outside the eustoma greenhouses and in front of the seedling terrace. Samples taken near the entrances to the greenhouses were not always contaminated, suggesting that the pathogen was not brought into the greenhouses on the feet of greenhouse workers. On the other hand, $P$. irregulare was not detected in either the water supply well or seedling terrace over the sampling period, and was detected in multiple blocks at the same transplanting periods. These results suggested that the most likely timing for the introduction of the pathogen to the seedlings and the culture blocks was when the seedlings were transplanted to the greenhouses, and that the pathogen most likely came from the soil. Furthermore, the relationship between the transplanting dates and the timing of detection suggest that the culture system may become infested regardless of the season, even though the optimum growth temperature of $P$. irregulare is 24 to $26^{\circ} \mathrm{C}$, corresponding to the spring and autumn in Fukushima, Japan.

In theory, the detection limit of the pathogen is one zoospore per 4 liters of nutrient solution using MC-LAMP. Therefore, the pathogen might have been present in some blocks where it was not detected. This hypothesis could explain why $P$. irregulare was detected in some nutrient solutions several months after the disinfestation of the cultivation equipment. This result also demonstrates that the sterilization method may not be sufficient, especially at high degrees of infestation. If residues of infected roots remain in the culture panels, the panels will be difficult to sterilize and may lead to successive infestations.

Eustoma disease occurred infrequently during the early growth stage and much more frequently at the late growth stage. At the flowering stage, in particular, eustoma requires large amounts of water for photosynthesis; therefore, damaged roots will lead to wilting. $P$. irregulare was detected in the nutrient solution in all blocks where the disease occurred. Also, the pathogen was sometimes detected in healthy roots before the disease symptoms were visible. The vulnerability of the host plants and environmental factors favorable to the pathogen such as temperature will strongly influence disease occurrence. Therefore, a latency or low-grade infection period can occur between pathogen infestation and the occurrence of the disease. Moreover, in January 2017, four and seven blocks with a positive detection for nutrient solutions and roots, respectively, suggests that the detection sensitivity in roots is higher than nutrient solutions. These results indicate that monitoring the roots of symptomatic and asymptomatic plants is an essential step for early diagnosis of disease occurrence.

Based on the results of this study, we propose the following important strategies to prevent diseases in hydroponic culture systems. (i) The complete isolation of greenhouses from the surrounding soil is necessary. Trolleys used for transplanting seedlings and the shoes worn by workers need to be sterilized frequently. (ii) Once the pathogens are detected in the nutrient solutions, it is necessary to replace the nutrient solutions with sterilized water until zoospores cannot be detected after replacing the solutions. (iii) After harvest, a high-level sterilization process involving repeated heat sterilization of cultivation equipment two or more times is needed, especially in blocks where disease has occurred.

In conclusion, the periodic monitoring of pathogens in the culture systems and ground soils is very important for the management and prevention of diseases in hydroponic greenhouses.

\section{Literature Cited}

Agarwal, S., and Grover, A. 2006. Molecular biology, biotechnology and genomics of flooding-associated low $\mathrm{O}_{2}$ stress response in plants. Crit. Rev. Plant Sci. 25:1-21.

Asano, T., Senda, M., Suga, H., and Kageyama, K. 2010. Development of multiplex PCR to detect five Pythium species related to turfgrass diseases. J. Phytopathol. 158:609-615.

Atkinson, N. J., and Urwin, P. E. 2012. The interaction of plant biotic and abiotic stresses: From genes to the field. J. Exp. Bot. 63:3523-3543.

Baligar, V. C., and Fageria, N. K. 2015. Nutrient use efficiency in plants: An overview. Pages 1-14 in: Nutrient Use Efficiency: From Basics to Advances. A. Rakshit, H. B. Singh, and A. Sen, eds. Springer India.

Banko, T. J., Richardson, P. A., and Hong, C. X. 2006. Effects of zoospore concentration and application pressure on foliage blight of Catharanthus roseus caused by Phytophthora nicotianae. Plant Dis. 90:297-301.

Boubourakas, I. N., Fukuta, S., and Kyriakopoulou, P. E. 2009. Sensitive and rapid detection of peach latent mosaic viroid by the reverse transcription loopmediated isothermal amplification. J. Virol. Methods 160:63-68.

Chaves, M. M., and Oliveira, M. M. 2004. Mechanisms underlying plant resilience to water deficits: Prospects for water-saving agriculture. J. Exp. Bot. 55:2365-2384.

Domsch, K. H., Gams, W., and Anderson, T. H. 1980. Compendium of Soil Fungi, Vol. 1. Academic Press Ltd., London.

Feng, W., Ishiguro, Y., Hotta, K., Watanabe, H., Suga, H., and Kageyama, K. 2015. Simple detection of Pythium irregulare using loop-mediated isothermal amplification assay. FEMS Microbiol. Lett. 362:fnv174.

Fukuta, S., Takahashi, R., Kuroyanagi, S., Miyake, N., Nagai, H., Suzuki, H., Hashizume, F., Tsuji, T., Taguchi, H., Watanabe, H., and Kageyama, K. 2013. Detection of Pythium aphanidermatum in tomato using loop-mediated isothermal amplification (LAMP) with species-specific primers. Eur. J. Plant Pathol. 136:689-701.

Fukuta, S., Takeyama, K., Suzuki, M., Shichi, A., Ichikawa, K., and Nakanishi, H. 2012. Detection of Kyuri green mottle mosaic virus from soil by the immunocapture reverse transcription loop-mediated isothermal amplification reaction. Plant Pathol. J. 11:51-59.

Gamo, Y., Tojo, M., and Ohki, S. T. 2004. Evaluation of selective media using fluazinam or miconazole nitrate for quantitative isolation of Pythium spp from soil. Jpn. J. Phytopathol. 70:215.

Goto, M., Honda, E., Ogura, A., Nomoto, A., and Hanaki, K. I. 2009. Colorimetric detection of loop-mediated isothermal amplification reaction by using hydroxy naphthol blue. Biotechniques 46:167-172.

Granke, L. L., and Hausbeck, M. K. 2010. Effects of temperature, concentration, age, and algaecides on Phytophthora capsici zoospore infectivity. Plant Dis. 94:54-60.

Hong, C., Richardson, P. A., and Kong, P. 2002. Comparison of membrane filters as a tool for isolating pythiaceous species from irrigation water. Phytopathology 92:610-616.

Ishiguro, Y., Asano, T., Otsubo, K., Suga, H., and Kageyama, K. 2013. Simultaneous detection by multiplex PCR of the high-temperature-growing Pythium species: $P$. aphanidermatum, $P$. helicoides and P. myriotylum. J. Gen. Plant Pathol. 79:350-358.

Iwamoto, T., Sonobe, T., and Hayashi, K. 2003. Loop-mediated isothermal amplification for direct detection of Mycobacterium tuberculosis complex, $M$. avium, and $M$. intracellulare in sputum samples. J. Clin. Microbiol. 41: 2616-2622.

Kageyama, K., Ohyama, A., and Hyakumachi, M. 1997. Detection of Pythium ultimum using polymerase chain reaction with species-specific primers. Plant Dis. 81:1155-1160.

Kitamura, M., Aragane, M., Nakamura, K., Watanabe, K., and Sasaki, Y. 2016. Development of loop-mediated isothermal amplification (LAMP) assay for rapid detection of Cannabis sativa. Biol. Pharm. Bull. 39:1144-1149.

Li, M., Ishiguro, Y., Otsubo, K., Suzuki, H., Tsuji, T., Miyake, N., Nagai, H., Suga, H., and Kageyama, K. 2014. Monitoring by real-time PCR of three water-borne zoosporic Pythium species in potted flower and tomato greenhouses under hydroponic culture systems. Eur. J. Plant Pathol. 140:229-242.

Lim, C. W., Baek, W., Jung, J., Kim, J. H., and Lee, S. C. 2015. Function of ABA in stomatal defense against biotic and drought stresses. Int. J. Mol. Sci. 16: 15251-15270.

McCauley, A., Jones, C., and Jacobsen, J. 2009. Plant nutrient functions and deficiency and toxicity symptoms. Nutrient Management Module No. 9. Mont. State Univ. Ext. 4449-9.

Miles, T. D., Martin, F. N., and Coffey, M. D. 2015. Development of rapid isothermal amplification assays for detection of Phytophthora spp. in plant tissue. Phytopathology 105:265-278. 
Mittler, R. 2006. Abiotic stress, the field environment and stress combination. Trends Plant Sci. 11:15-19.

Miyake, N., Nagai, H., Kato, S., Matsusaki, M., Fukuta, S., Takahashi, R., Suzuki, R., and Ishiguro, Y. 2017. Practical method combining loop-mediated isothermal amplification and bait trap to detect Pythium helicoides from hydroponic culture solutions. J. Gen. Plant Pathol. 83:1-6.

Mori, Y., Kitao, M., Tomita, N., and Notomi, T. 2004. Real-time turbidimetry of LAMP reaction for quantifying template DNA. J. Biochem. Biophys. Methods 59:145-157.

Mori, Y., Nagamine, K., Tomita, N., and Notomi, T. 2001. Detection of loopmediated isothermal amplification reaction by turbidity derived from magnesium pyrophosphate formation. Biochem. Biophys. Res. Commun. 289:150-154.

Morita, Y., and Tojo, M. 2007. Modifications of PARP medium using fluazinam, miconazole, and nystatin for detection of Pythium spp. in soil. Plant Dis. 91: 1591-1599.

Notomi, T., Okayama, H., Masubuchi, H., Yonekawa, T., Watanabe, K., Amino, N., and Hase, T. 2000. Loop-mediated isothermal amplification of DNA. Nucleic Acids Res. 28:e63.

Rigano, L. A., Marano, M. R., Castagnaro, A. P., Do Amaral, A. M., and Vojnov, A. A. 2010. Rapid and sensitive detection of citrus bacterial canker by loopmediated isothermal amplification combined with simple visual evaluation methods. BMC Microbiol. 10:176.

Schroeder, K. L., Okubara, P. A., Tambong, J. T., Lévesque, C. A., and Paulitz, T. C. 2006. Identification and quantification of pathogenic Pythium spp. from soils in eastern Washington using real-time polymerase chain reaction. Phytopathology 96:637-647.

Schwenkbier, L., Pollok, S., König, S., Urban, M., Werres, S., Cialla-May, D., Weber, K., and Popp, J. 2015. Towards on-site testing of Phytophthora species. Anal. Methods 7:211-217.
Shen, D., Li, Q., Yu, J., Zhao, Y., Zhu, Y., Xu, H., and Dou, D. 2017. Development of a loop-mediated isothermal amplification method for the rapid detection of Pythium ultimum. Australas. Plant Pathol. 46:571-576.

Stanghellini, M. E., and Rasmussen, S. L. 1994. Hydroponics. A solution for zoosporic pathogens. Plant Dis. 78:1129-1138.

Tamai, D. 2014. The practical cultivation and technologist training in tomato low node order pinching and high density planting cultivation. Shisetsu-to-Engei 165:62-65. (In Japanese.).

Tauzin, A. S., and Giardina, T. 2014. Sucrose and invertases, a part of the plant defense response to the biotic stresses. Front. Plant Sci. 5:293.

Tomlinson, J. A., Dickinson, M. J., and Boonham, N. 2010. Detection of Botrytis cinerea by loop-mediated isothermal amplification. Lett. Appl. Microbiol. 51: 650-657.

Van der Plaats-Niterink, A. J. 1981. Monograph of the genus Pythium. Studies in Mycology, 21. Centraalbureau voor Schimmelcultures, Baarn, The Netherlands.

Vollenweider, P., and Günthardt-Goerg, M. S. 2005. Diagnosis of abiotic and biotic stress factors using the visible symptoms in foliage. Environ. Pollut. 137:455-465

Wang, W., Vinocur, B., and Altman, A. 2003. Plant responses to drought, salinity and extreme temperatures: Towards genetic engineering for stress tolerance. Planta 218:1-14.

Watanabe, H., Kageyama, K., Taguchi, Y., Horinouchi, H., and Hyakumachi, M 2008. Bait method to detect Pythium species that grow at high temperatures in hydroponic solutions. J. Gen. Plant Pathol. 74:417-424.

Zhang, Y., Kiriiwa, Y., and Nukaya, A. 2015. Influence of nutrient concentration and composition on the growth, uptake patterns of nutrient elements and fruit coloring disorder for tomatoes grown in extremely low-volume substrate. Hortic. J. 84:37-45. 